\title{
Social iniquities in Primary Healthcare and intersectoral action: a descriptive study
}

As iniquidades sociais da Atenção Primária à Saúde e a intersetorialidade: um estudo descritivo Las iniquidades sociales de la Atención Primaria a la salud y la intersectorialidad: un estudio descriptivo

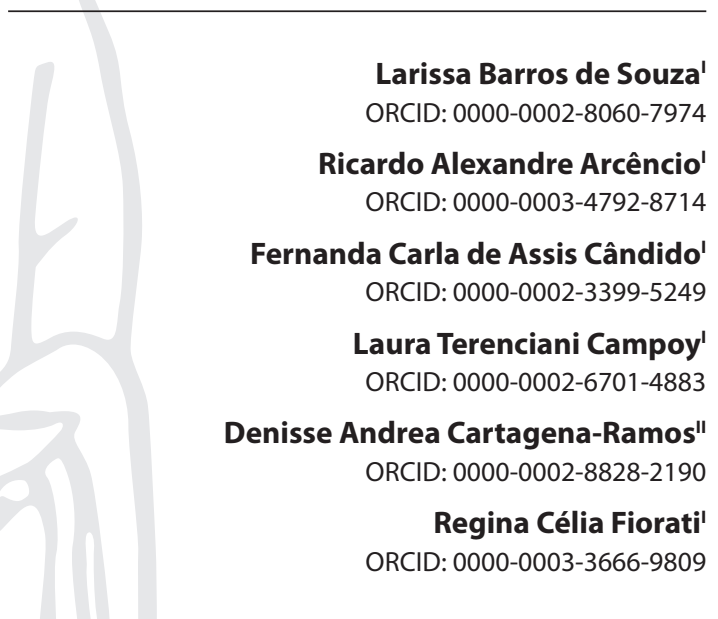

'Universidade de São Paulo. Ribeirão Preto, São Paulo, Brazil. "Universidad Andrés Bello. Santiago, Chile.

How to cite this article: Souza LB, Arcêncio RA, Cândido FCA, Campoy LT, Cartagena-Ramos DA, Fiorati RC. Social iniquities in Primary Healthcare and intersectoral action: a descriptive study. Rev Bras Enferm. 2020;73(6):e20190196. doi: http://dx.doi.org/10.1590/0034-7167-2019-0196

Corresponding author: Larissa Barros de Souza E-mail: tobarros@usp.br

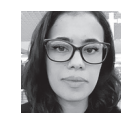

EDITOR IN CHIEF: Antonio José de Almeida Filho ASSOCIATE EDITOR: Priscilla Broca

Submission: 07-24-2019

Approval: 04-13-2020

\begin{abstract}
Objective: To analyze Primary Healthcare with regards to dealing with social inequities through actions targeted at Social Determinants of Health, from the perspective of Family Health Strategy Professionals. Methods: Descriptive study with a qualitative approach. Data were collected through focus groups and analyzed using Habermas's communicative action theory. Results: There were few intersectoral and assistance organization actions with clinical emphasis; municipal management for intersectoral actions shows a lack of planning and faces challenges; and there is little communication and articulation between the sectors. Final considerations: There are many challenges to be overcome by Primary Health Care to contemplate intersectoral actions targeted at Social Health Determinants, a demand inherent to the possibilities of advancing in the reduction of social and health-related inequalities. Descriptors: Inequality; Primary Health Care; Intersectoral actions; Health Social Determinants; Social Vulnerability.
\end{abstract}

\section{RESUMO}

Objetivo: Analisar as práticas da Atenção Primária à Saúde no que tange ao enfrentamento das iniquidades sociais mediante ações voltadas aos Determinantes Sociais da Saúde, sob a ótica de profissionais da Estratégia de Saúde da Família. Métodos: Estudo descritivo com abordagem qualitativa. Por meio de grupos focais, foram coletados os dados, para cuja análise utilizou-se a teoria da ação comunicativa, de Habermas. Resultados: Observaram-se poucas ações desenvolvidas no âmbito intersetorial e de organização assistencial com ênfase clínica; falta de planejamento e dificuldades de gestão municipal para a intersetorialidade; $\mathrm{e}$ falta de comunicação e articulação entre os setores. Considerações finais: Há grandes desafios a serem enfrentados pela Atenção Primária à Saúde para contemplar ações intersetoriais voltadas aos Determinantes Sociais da Saúde, uma demanda inerente à possibilidade de avanço na redução das desigualdades sociais e em saúde.

Descritores: Iniquidades Sociais; Atenção Primária à Saúde; Intersetorialidade; Determinantes Sociais da Saúde; Vulnerabilidade Social.

\section{RESUMEN}

Objetivo: Analizar las prácticas de la Atención Primaria a la Salud en lo que respecta al enfrentamiento de las iniquidades sociales mediante acciones vueltas a los Determinantes Sociales de la Salud, bajo la óptica de profesionales de la Estrategia de Salud de la Familia. Métodos: Estudio descriptivo con abordaje cualitativo. Por medio de grupos focales, han sido recogidos los datos, para cuyo análisis se ha utilizado la teoría de la acción comunicativa, de Habermas. Resultados: Se observaron pocas acciones desarrolladas en el ámbito intersectorial y de organización asistencial con énfasis clínico; falta de planeamiento y dificultades de gestión municipal para la intersectorialidad; y falta de comunicación y articulación entre los sectores. Consideraciones finales: Hay grandes desafíos a ser enfrentados por la Atención Primaria a la Salud para contemplar acciones intersectoriales vueltas a los Determinantes Sociales de la Salud, una demanda inherente a la posibilidad de avanzo en la reducción de las desigualdades sociales y en salud.

Descriptores: Iniquidades Sociales; Atención Primaria a la Salud; Intersectorialidad; Determinantes Sociales de la Salud; Vulnerabilidad Social. 


\section{INTRODUCTION}

From the last quarter of the 20th century, there was an increase in the number of studies about health inequalities in social groups within specific countries and between countries, from many different regions of the world. As a result, the Commission on Social Determinants of Health was created by the WHO (CSDH-WHO/ $\mathrm{WHO}^{(1)}$ in 2005. From this event on, and stemming from policies implanted due to the recommendations of this commission, studies have pointed out some advances in regards to the diminution of inequalities in health, especially in Europe ${ }^{(2)}$.

Health inequality is a term that refers to the differences in the state of health between different socioeconomic groups. In addition to being systematic and relevant, they are also avoidable, unjust, and unnecessary ${ }^{(3)}$. These inequities are based, directly or indirectly, on social, economic, and environmental factors, and there is no biological reason for their existence. They can, therefore, be changed ${ }^{(4)}$. However, in Brazil, as well as in many other regions of the world in which there are frequent poverty pockets, social inequalities are still frequent and the access to material and symbolic resources is unequal, impacting the health of people and of entire populations ${ }^{(5-7)}$.

According to the recommendations of the $\mathrm{CSDH}-\mathrm{WHO}^{(5)}$, intersectoral policies are among the main actions to confront health inequality. Intersectoral actions integrate and articulate multiple pieces of knowledge and experiences from different subjects and services that collaborate in the confrontation of complex problems, with actions targeted at the collective interest that can improve the efficiency of the political management of the services offered ${ }^{(8-10)}$. For the re-elaboration of the National Policy of Health Promotion ${ }^{(11)}$, this intersectoral articulation and cooperation means the sharing of plans, resources, and common objectives among different sectors. One of its directives is the encouragement of these practices, to expand actions towards health determinants and requirements.

Intersectoral Actions in health are important components of the Global Strategy for Health for All by the Year 2000, which resulted from the Alma Ata Conference. The same is true for the component "Health in All Policies" (HiAP), from 2006. The HiAP approach promotes effective and systematic actions to improve the health of the population, truly using all measures available in all political fields ${ }^{(12-14)}$.

Health in All Policies is an intersectoral policy on the superstructure level of governments. It is urgent and indispensable. On the other hand, intersectoral strategies must take place considering communities and the civil society, in order to carry out actions towards diminishing social inequities, considering the growth of social issues in the urban territories of large and medium cities in the world, especially in poor or developing cities ${ }^{(1,14-18)}$.

Intersectoral actions, resulting from the Primary Healthcare (PH) and articulated with other public management sectors from civil society, have been pointed out, by studies in many regions of the world, as successful in their reduction of health inequalities. Some of these actions are: the creation of programs targeted at the inclusion in the work market with a higher income, increased access to health and education services, the creation of programs targeted at the environmental fields, and the fostering of social capital in communities. All that empowers groups, increases social participation from the civil society, improves the gradient in health in the populations studied, improves the state of health of specific groups analyzed, and the ability to confront diseases that are considered poverty-related or that are neglected ${ }^{(6,19-26)}$.

However, in Brazil, there is a lack of studies that map and evaluate intersectoral programs $s^{(6,10)}$. The issues to be considered are: How did the Brazilian government define an agenda and adopted intersectoral strategies to overcome the social inequality in vulnerable groups or territories, and what is the role of $\mathrm{PH}$ in this process? What are the strategies defined by these actors to deal with social inequality? Although social inequality is a big obstacle to the objective of making health available to all, we found few studies in Brazil that address this issue.

Aiming to answer to these questions, this study shows its relevance, as it highlights intersectoral action as a way to manage public policies that can be used to face inequalities in the primary level of health care, attending to this important recommendation by the WHO. Intersectoral action has shown itself to be a powerful tool, but the construction of intersectoral policies, organized in networks to confront inequalities, is still a great challenge Brazilian $\mathrm{PH}$. As a result, it is necessary to seek what are the main potentials and difficulties found by the professionals in the creation and implementation of these networks.

\section{OBJECTIVE}

Analyzing $\mathrm{PH}$ practices, from the perspective of Family Health Strategy (FHS) workers, with regards to dealing with social inequities through actions targeted at Social Determinants of Health (SDH).

\section{METHODS}

\section{Ethical aspects}

This research was approved by the Research Ethics Committee, according to Resolution No. 466/2012 from the National Council of Health, which elaborates the norms regulating researches with human beings.

\section{Type of study}

This is a quantitative, descriptive study, based on the theoretical framework of Habermas's Critical Hermeneutics and its communicative action theory, using focal groups as data collection instruments.

To direct the writing of this article, the instrument Standards for Reporting Qualitative Research (SRQR) ${ }^{(27)}$, a guide for the EQUATOR Network, was used ${ }^{(28)}$.

\section{Study setting}

The study was carried out in a Brazilian city in the countryside of the state of São Paulo, in the Southeast region of the country. The city has $650.916 \mathrm{~km}^{2}$ and its population, as estimated by the Brazilian Institute of Geography and Statistics (IBGE) ${ }^{(29)}$ was of 682,302 residents, as of 2017. 
According to the $\mathrm{IBGE}^{(29)}$, the district selected has groups with high social vulnerability. The territory has favelas, defined by the IBGE as urban areas which are inhabited in the cities and devalued by the real state and land property sectors - houses there do not have titles of property and are in irregular streets, in lots that are irregular in their form and size. They also lack essential public services (garbage removal, sewage system, water system, electric energy, and public lighting). This region, selected by the study, involves eight Primary Healthcare Units (PHUs) and ten Family Health Strategy (FHSs) units. Three of the latter were selected, as they were units that are geographical references for three of these favelas.

\section{Study population}

This study counted on 42 participants, health professionals from different fields and areas, integrating the minimum FHS team.

\section{Data collection}

Three focal groups were organized and carried out with the participants. All professionals present on the date scheduled participated. The groups lasted from 40 minutes to 1 hour and presented 3 questions to be discussed (Chart 1). Each focal question lasted for about 15 minutes. Audio recorders were used, and the recordings were later transcribed for data analysis.

Chart 1 - Questions used in the focal groups

1 - What are the strategies used by your Family Health Center to focus on SDHs?

2 - In your opinion, what is the potential and what are the advantages of this territory for the creation of intersectoral programs to confront social inequalities in partnership with other sectors, such as social assistance, education, and others?

3 - What are the obstacles for the creation of intersectoral programs targeted at confronting social inequalities in health in your territory?

\section{Data analysis}

Data analysis followed the theoretical framework of Jürgen Habermas's Critical Hermeneutics, based on his communicative action theory. To analyze the data, this study used criteria for the validity of linguistic enunciates for a dialogic communication capable of forming based consensus, according to Habermas ${ }^{(30)}$. These criteria are threefold: 1 ) the enunciates must have a propositional truth about the objective world, referring to the shared experiences of a social group; 2 ) they must have normative rightness about the shared and socially-built world, which refers to culture and the norms of the institutions that make it up; 3 ) and a subjective truth presented by authentic enunciates targeted at the good of the public and free from private interest. These will, therefore, be the criteria for the analysis of the enunciates that made up the discussions on the focal groups.

Therefore, based on this script (comprehensive analysis of what was said, insertion of enunciates in a normative and cultural context, also taking into account their authenticity), the enunciates were, finally, interpreted based on the generative conditions of the points brought forth by the participants, which made these communications possible within a symbolic context that is its pillar ${ }^{(31)}$.

Therefore, after data organization, the interpretative-reconstructive hermeneutic approach, according to Habermas ${ }^{(30)}$, was carried out through the reading and re-reading of the information in the transcriptions, according to the plan below:

1. Organizing the linguistic content enunciated, which corresponds to the set of objective experiences shared and reported by the participants, that is, "what they said", corresponding to Habermas's 1st condition of validity (propositional truth);

2. Then, the material produced in the first stage was analyzed taking into account its normative correction in the social world: the cultural, political, economic, historical, and social settings from which the enunciates found the references upon which they were constructed (Habermas's 2nd condition of validity);

3. Later, there was an analysis of the enunciates according to the pretension of veracity validity, based on the subjective authenticity of the enunciates and seeking to understand them in accordance to the social needs of the context of the public sphere in which the services must attend to the community that receives the service (Habermas's 3rd condition of validity - subjective veracity);

4. In the last stage of analysis, the interpretation of the communicative process in the focal groups (articulating analysis of the enunciates according to the three conditions of validity proposed by Habermas). Considering the objective of the research as a reference, an analysis was carried out to reconstructively discover the generative structures that underlie the production of the symbolic formation of the discourses, that is, the reasons that led participants to bring forth certain arguments, inserted in their time and space, which resulted in those specific discourses and not in others, in the argumentation process.

The materials regarding Stage 1 are presented in the results, while the later stages ( 2 to 4 ) are the actual activities of data analysis and interpretation.

\section{RESULTS}

Below, the relevant themes that emerged from the questions used in the focal groups are described. They were: "How do the Family Health Centers (FHCs) operationalize the SDHs in their territory and in the community they attend?", "The potential for the creation of intersectoral programs to confront social inequality", and "Difficulties to create intersectoral programs to confront social inequalities in health".

\section{The operationalization of Social Determinants of Health (SDH) in the territory and in the community attended}

Regarding the first question addressed, discussions presented some relevant statements, indicating house visits, team reunions, referrals, and income groups as ways to approach the SDHs. 
- House visits from community health agents (CHAs) and other professionals: means through which social vulnerability situations are identified which interfere in the health of people involved;

[...] I work in the houses, with the people, with the knowledge we have about them, with time you build a better relationship and get to know certain things about these determinants. Some of them are in a serious situation of poverty, of drug abuse, alcohol, violence, so I think we get to know that in a day-to-day basis, the actions are based on that. (CHA - Focal Group 3)

- Team meetings to discuss the cases: event in which the conditions are evaluated, as well as the social factors that could interfere in the health condition of the user, after which a plan of action is decided upon;

[...] the first thing is having a team meeting in the houses, then, according to the family and their needs, we move. (Resident Physician - Focal Group 2)

- Referral to other devices and services from different sectors: also cited as paths for social factors to be worked, with an impact in the health of users;

[...] in the family discussions we make, that's were these themes are brought forth, then we get in touch with the [Child Protection] Services, with the Social Assistant, we ourselves get in touch and advise the family to seek them [...] (Resident Physician - Focal Group 3)

- Group of income generation: developed by some CHAs with the women in the community. However, there was no interaction with other sectors, and the group meetings were terminated due to the reduction in the resources offered by the Secretariat of Health.

All groups mentioned that few actions are developed with other sectors. They mention institutionalized intersectoral programs ("Saúde na Escola" and "Bolsa Família" - "Health in School" and "Family Pensions", respectively), in which it is also difficult to share the management. They also report that, locally, they cannot implement intersectoral actions targeted at the SDHs. The actions carried out are isolated in each service and sector, even when they do the same with similar objectives, in the same families within the same community.

The intersectoral actions that I see here in the city, the segments work well, but apart. This group work doesn't exist, this plan doesn't exist in the territory, there is no plan in the city to attend. So what we have is that each secretariat, each sector, they do some work and try to seek the work, the help, of another secretariat. So, in this case, I think that the Health in School program is a program that integrates school and health. But these intersectoral actions that should exist in the plan does not. [Coordinator of the Center - Focal Group 1]

[About the relations with the CRAS (the Center of Reference for Social Assistance]) We use to advise when we see that they need some advice, we use to give the address, the phone, depending on the case we call there ourselves so the person can go already referred to a specific person, but you have to know its something very different from our daily lives. We know it's there, we use it, but we rarely sit together to talk and do something together. (Nurse - Focal Group 2)

\section{The potential of the territory for the creation of intersec- toral programs targeted at the Social Determinants of Health (SDH)}

Regarding the second focal question, the participants mentioned, as potential actions targeted at the SDHs and developed between sectors: the very PHC model, the federal intersectoral programs, interdisciplinarity, the social assistance service, the Local Council of Health, the Neighborhood Association, the community in the scope of the service, and cooperatives.

- Intersectoral actions as part of the PHC model;

- Federal intersectoral programs: such as "Health in School" and "Family Pensions";

But I think that the program that we do together is Health in School, because we go, we stay, we exchange information with the teachers, directors, sometimes they present some demand, and we try to help them with it. (Unit physician - Focal Group 1)

- Interdisciplinarity: pointed out due to the fact that multiple sectors are involved, which takes place due to the presence of courses from the health field in the local university;

[...] even considering the dialog within university, the health services, and other segments. I think that since this is a district that is constantly related to the university, that also makes it possible to develop many actions that can lead to these intersectoral actions. [...] Our greatest potential is the interdisciplinary team with us; that's what helps us, that's why we don't have a a lot of other cases. (Dentistry Professor - Focal Group 1)

- Social Assistance: despite being mentioned as a potentiality, the social assistant usually required is stationed in health. It is difficult to find them both in searches in the CRAS of the region and in intersectoral actions that involve social assistance, due to the lack of human resources in this sector;

The person we access the least is the one [social assistant] from the CRAS. Normally we have one in health that helps us, the CRAS gives advice, the address, people are informed about it, but we do need to work more closely. (Resident Physician - Focal Group 3)

The greatest difficulty is that there is a social assistant for the whole district, so she can't come here and work in a group action, because there is a whole district with units which might be more vulnerable than ours. So I think we should have more social assistance, with more working hours. Or even in the unit. (Unit physician - Focal Group 1)

- Local Health Council (LHC) and Neighborhood Association: community associations that unite to demand social improvements: 
A potential here, I think it's the $L H C$, because it's from the perspective of the population. Our region already has a very old neighborhood participation with the Neighborhood Association. The Association started through local health commissions, and then, now with the LHCS, they bring demands that are changing health. So this articulated work with the population with the [family health] units has been moving. (Coordinator of the Center - Focal Group 1)

- Attended community: the community is very interested and participative;

There is the local commission too, in which we participate a lot. They always help, it's work we do together: community and health services, for example, its the Council, which belongs to the 6 centers simultaneously. We are always together struggling to help the other, for the improvement not only of the unit, but of the population as well. And the population has adhered more and more. (CHA-Focal Group 2)

- Cooperatives of solid residue collectors: the need for social investment for the creation of such cooperatives was pointed out, due to the frequent presence of collectors as family heads in the region.

I think that, as a potential, we also have a lot of people who work collecting recyclable waste [...] sometimes we see some people even, probably, making some money with it. Maybe, there's potential to create some cooperative or auxiliary. There's a lot. There is potential in it, we even thought about it [creating a cooperative]. [...] (Resident Physician - Focal Group 3)

\section{Difficulties to create intersectoral programs to confront Social Determinants of Health (SDH)}

With regards to the third focal question, when dealing with the difficulties in creating intersectoral actions, the themes brought forth were regarding management and the lack of planning from the government, to the difficulties of communication and articulation between the sectors, to the organization of work which is still focused on clinical assistance, and on the bureaucracy there is in the government and secretariats.

- Lack of planning and management from the government: no public policies aimed at confronting social programs have a strong presence in the communities, and they do not guide the sectors to considering this as a priority in their actions; also, municipal management shows no interest in the creation of policies to elaborate, implant, and manage social issues in an intersectoral manner, through the implantation of intersectoral programs and actions, central or local.

The city has no plan, no social policy. It has a Health Plan, an Education Plan, it has a Social Assistance Plan, but each is a separate plan, they are not connected, to create a type of planning that is a global and intersectoral program. So the municipal government should create a global plan which integrated all secretariats; I think that would save a lot of money and would be more efficient in solving the problems. (Coordinator of the Center - Focal Group 1)

But the feeling is that we lack someone who can see things from above, that can manage and nudge us, provoke us, because sometimes the fire starts to fade. Sometimes the need is here, and we move, and that sort of gives a direction, kind of, to things, and we settle down and don't bring forward intersectoral projects. (Nurse - Focal Group 2)

I think that the municipal administration could generate intersectoral actions, kind of opening space for the service, like "oh, we'll have a moment to solve", to have a moment that's scheduled and guaranteed for when we need a meeting. So that cases can be discussed in group, there should be a scheduling system, an agenda, you know... it would be interesting, because that can protect. I see a lot of motivation, I see many looks, consideration for all this, with all these issues, but I think we still don't have this culture that can really involve the sectors that could work together until a better result is found [...] and when you search, sometimes no one listens, no one is receives it sensibly; I think that discourages too. (Resident Physician - Focal Group 3)

- Lack of communication, exchange, and articulation between sectors: this results from the lack of knowledge of the managers and professionals about what intersectoral actions are, leading to shortcomings in organization and articulation with regards to it. Therefore, there is a lack of culture for intersectoral work, which generates sectoral isolation and sporadic and ad hoc group actions, with no articulation, planning, coordination, and continuity.

[...] the work in health and the work in other sectors can be very well done, but they end up losing a bit of their efficiency, since there is no communication between the different secretariat sectors and sectors within the health secretariat itself. (Coordinator of the Center - Focal Group 1)

[...] not only there are difficulties in communication, it seems there is... lack of interest, from some people in some sectors, right? We feel an indifference, some sectors remain silent about our demands. (Nurse - Focal Group 2)

- Bureaucracy: present in the administrative levels of the government and secretariats;

[...] one of the difficulties is the issue of bureaucracy; sometimes different sectors are asking or referring the same thing. So I think this articulation is made more difficult in health due to the management of the secretariat itself. (Coordinator of the Center - Focal Group 1)

- The work in the FHCs and in other PHC services is still strongly organized to offer clinical care, which prevents actions targeted at the SDHs to be treated as a priority.

I can talk for me, in my case what I can say is the time to do it. Availability, because although this isn't the philosophy, we are still mostly in assistance, individual attention, well, this is what I find difficult. (Physician - Focal Group 2)

\section{DISCUSSION}

Considering the objective of this research, which was analyzing the $\mathrm{PHC}$ practices with regards to confronting social inequalities through actions targeted at the SDHs, from the perspective of health workers, it became clear that one theme was recurrent in the arguments of the participants: the practice of referrals as intersectoral actions. 
This shows that the participants have a superficial understanding of the concept of intersectoral action, although they point out that it is an action that constitutes the policies of PHC in the world, and the Primary Healthcare Policies in Brazil. Another information that recurred was the predominantly clinical organization of the services studied. That denotes tension between the model that defines the $\mathrm{PHC}$ and the actual practices made available by Primary Healthcare services, as they are called in Brazil.

The PHC model in Brazil, created according to the recommendations of the Alma-Ata International Conference (1976), prescribes that the $\mathrm{PHC}$ should be the device that reorganizes the Single Health System (SUS). It should have in its core the social issues related to health and the need of a healthcare model that is focused on the territory and on the communities, and targeted at the social determinants of health and the fight against poverty, to prevent and promote health, being connected through intersectoral networks. In the legacy of the Alma-Ata Conference, therefore, this concept of the organization of national health systems is connected to the many economical crises that the capital imposes and to its relations with the emergence of urban geographic regions of extreme poverty, as well as the social inequality in health ${ }^{(32-33)}$.

Therefore, in Brazil, the context of the PHC, although it was created on the discourse according to which it should be the device that organizes the system and recognizes the social health determinants, is in a constant dilemma that results from the practical clinical-organicist conceptions that predominate in the education of the health professionals in the system ${ }^{(34-35)}$. Therefore, the context of the PHC is the arena in which there is a dilemma which raises a conflict between two concepts and their contradictory practices: the traditional biomedical one, and the social determination of health one ${ }^{(36)}$. Consequently, in this context, contradictory discourses are produced about the SDHs and their operationalization through intersectoral measures. Although there is a recognition that actions targeted at the SDHs are carried out in the PHC context, the lack of knowledge about the concept of intersectoral action is clear, since it is understood from a logic that associates it with referrals. Also, the discourses show that the service has a predominantly clinical organization, prioritizing individual clinical consultations over SDH-targeted actions. Even those who act in a different way, the CHAs, do it from a predominantly clinical logic.

Another important context in which the enunciates and discourses are produced is the social, historical, economical, and political context of the Brazilian society. The statements mentioned, as one of the factors that prevent intersectoral actions - as a way to manage public policies targeted at complex social issues - the way in which the Brazilian society is governed.

The interpretation of these statements suggests that the type of government in Brazil makes it more difficult to manage public policies in an intersectoral manner. That would mean that governors reproduce a conduct that puts the interests of a few private parties above the interests of society as a whole, devaluing management methodologies based on the distribution of power and shared decision-making.

Another important factor that marks the generative social structures of the arguments of the participants is related to the culture and to Brazilian social values. That is connected to the degree of solidarity that marks the social relations of a people and is defined by the limits up to which a society can endure the social inequalities that make it up ${ }^{(37)}$.

One interpretation for this analysis can be based on studies ${ }^{(37-39)}$ according to which Brazilian society has little social cohesion and few social relations based on solidarity bonds. These studies state that Brazilian society tends to naturalize poverty and is resistant to social protection policies for groups in social vulnerability. This feature of Brazilian society is explained as the legacy of the culture in which a slaveholding sociopolitical organization was predominant until the end of the XIX century ${ }^{(38)}$. In this process, there is an unequal exercise of citizenship. Society often offers passive authorization to the frequent violation of the rights of persons and groups, and to the resistance of dominant social sectors with regards to social policies, strong social bonds and social cohesion ${ }^{(39)}$

A culture that values the bonds of solidarity formed by social cohesion and that produces social capital is pointed out as a strong element for the connection of structural and intermediary determinants in the structure and model for the SDHs built and adopted by the $\mathrm{CSDH}-\mathrm{WHO}^{(5)}$.

The current political context is not favorable to the elaboration and implantation of social public policies and is organized around neoliberal guidelines, which prioritize an economic model of wealth concentration as opposed to a distributive model, and is based on a model of economic development that is not regulated by the State, and includes the minimization of social policies. Therefore, within this political setting, the enunciates of the participants of the study reflect contradictory actions in the $\mathrm{PHC}$, since it cannot act in accordance to its primary principles, which include a concept of health-diseases that stem from a social perspective, and reproduces an attention model that is opposed to the health policies that generated it. Additionally, it does not develop effective actions targeted at the SDHs and delegates, through referrals, the resolution of social issues to other sectors and social agents, despite the fact that these social issues interfere and determine the health of their users ${ }^{(38-39)}$.

It is important to mention that, in Brazil, the PHC and FHS services still offer limited coverage, and the current Brazilian political environment is opposed to their development, as the reduction of the Single Health System budget which took place last year shows ${ }^{(40)}$.

As a result, in this setting, it is extremely difficult to implant the recommendations of the $\mathrm{CSDH}-\mathrm{WHO}^{(5)}$ called "Health in all policies", due to the type of government that is being consolidated in Brazil. Similarly, intersectoral actions involving civil society are very distant from being included. Brazilian society is in a fragmented context. It gradually watches important losses in its rights and democracy, which are essential elements of a people's health gradient, and essential to diminishing social inequalities in health.

The general results of this study reiterate previous statements on the lack of political interest from governments (federal and local) to institutionalize and prioritize public policies that work according to intersectoral networks. This makes it so the agendas of different sectors are not in line, prejudicing the advances of strategies to manage public policies that would be more efficient 
in the management of contemporary social complex issues. Therefore, the gaps in knowledge about this theme, in Brazil, suggest the need of researches that can evaluate successful experiences of intersectoral strategies which can offer the State and civil society the instruments required for managing public policies, targeted at the complexity of social issues.

\section{Study limitations}

The limitations of this study were the number of services involved and of focal group carried out. Therefore, other, broader works, or even researches that can involve a higher number of services, should be developed.

\section{Contributions for public Health and Policies}

The relevance of this research is in the fact that it is a diagnostic study, which can show, despite dealing with an extract of the population, a reality that still informs the settings of the Primary Healthcare Services in Brazil.

\section{FINAL CONSIDERATIONS}

This study aimed to analyze PHC practices, from the perspective of Family Health Strategy professionals, with regards to confronting social inequalities and poverty in the territories through actions targeted at the SDHs.

Regarding the operationalization of the SDHs in the services, the referrals are seen as intersectoral actions, in addition to improvised actions targeted at the SDHs and small actions carried out in tandem with sectors other than health, which are disarticulated, and lack continuity and coordination. With regards to the potential of intersectoral actions to confront the inequalities that impact the health of the population, actions in the community were mentioned, as well as some actions of associations and organizations that represent local civil society, and partnerships with the university and with intersectoral systematized programs implemented. Regarding difficulties to create intersectoral programs, the study shows: lack of exchange from PHC agents with other sectors; a culture of sectorial isolation; a lack of management, planning, and scheduling from the government for actions targeted at social issues and at carrying out intersectoral actions as a way to manage policies to confront these issues; organization of the PHC services that are still focused on clinical assistance; lack of human and material resources in the services.

The study has shown that the PHC still needs to confront many challenges to be able to offer intersectoral actions targeted at the SDHs, a demand which is inherent to the possibilities of diminishing social inequalities in health. The importance of this study is in the presentation of data that evidence the difficulties that PHC and Brazilian society as a whole have to act in accordance to the basic recommendations from the WHO as expressed in the $\mathrm{CSDH}$, recommendations that aim to confront and eradicate health inequalities between countries and inside countries and have intersectoral actions as their main strategy to confront these issues.

\section{FUNDING}

Unified Scholarship Program of the University of São Paulo.

\section{REFERENCES}

1. Commission of Determinants of Health (CSDH). Closing the gap in a generation: health equity through action on the social determinants of health. Final Report of the Commission on Social Determinants of Health. Geneva, World Health Organization. Lancet [Internet]. 2008 [cited 2019 Jan 28];372:1661-9. Available from: https://apps.who.int/iris/bitstream/handle/10665/69832/9786161101855_tha.pdf

2. Marmot M, Stuart K, Soulsby EJL. Reducing global health inequalities. Part 1. JRSM open [Internet]. 2011 [cited 2019 Feb 14]; 104:321-26. doi: $10.1258 /$ jrsm.2011.100396

3. Whitehead, M. The concepts and principles of equity in health. Int J Health Serv. 1992;22(3):429-45. doi: 10.2190/986L-LHQ6-2VTE-YRRN

4. Whitehead M, Dahlgren G, World Health Organization. Regional Office for Europe. Levelling up (part 1): a discussion paper on concepts and principles for tackling social inequities in health [Internet]. Copenhagen: WHO Regional Office for Europe. 2006[cited 2019 Feb 14]. Available from: https://apps.who.int/iris/handle/10665/107790

5. Solar O, Irwin A. A conceptual framework for action on the social determinants of health. Social Determinants of Health Discussion Paper 2 (Policy and Practice). WHO: Geneva, 2010.

6. Andrade LOM, Pellegrini-Filho A, Solar O, Rígoli F, de Salazar LM, Serrate PC, et al. Social determinants of health, universal health coverage, and sustainable development: case studies from Latin American countries. Lancet. 2015;385:1343-51. doi: 10.1016/S0140-6736(14)61494-X

7. World Health Organization-WHO. State of inequality-reproductive, maternal, newborn and child health. Genebra: OMS; 2015.

8. Junqueira LAP. Intersetorialidade, transetorialidade e redes sociais na saúde. Rev Adm Pública [Internet]. 2000[cited 2019 Feb 14];34(6):3545. Available from: http://bibliotecadigital.fgv.br/ojs/index.php/rap/article/view/6346

9. Inojosa RM. Sinergia em políticas e serviços públicos: desenvolvimento social com intersetorialidade. Cad Fundap [Internet]. 2001 [cited 2019 Feb 14];22:102-10. Available from: https://www.pucsp.br/prosaude/downloads/bibliografia/sinergia_politicas_servicos_publicos.pdf

10. Nascimento S. Reflexões sobre a intersetorialidade entre as políticas públicas. Serv Soc Soci. 2010;101:95-120. doi: 10.1590/ S0101-66282010000100006

11. Ministério da Saúde (BR). Portaria $n^{\circ}$ 2.446, de 11 de novembro de 2014. Redefine a Política Nacional de Promoção da Saúde (PNPS) [Internet]. Diário Oficial [da] União, Brasília, DF, 2014[cited 2019 Feb 14]. Available from: http://bvsms.saude.gov.br/bvs/saudelegis/gm/2014/prt2446_11_11_2014.html 
Social iniquities in Primary Healthcare and intersectoral action: a descriptive study Souza LB, Arcêncio RA, Cândido FCA, Campoy LT, Cartagena-Ramos DA, Fiorati RC.

12. Moral PAP, Gascón MLG, Abad ML. La salud y sus determinantes sociales: desigualdades y exclusión en la sociedad del siglo XXI. Rev Int Sociol [Internet]. 2014 [cited 2019 Feb 14];72(Supl 1):71-91. doi: 10.3989/ris.2013.02.16

13. Goeij MCM, Suhrcke M, Toffolutti V, Van de Mheen D, Schoenmakers TM, Kunst AE. How economic crises affect alcohol consumption and alcohol-related health problems: a realist systematic review. Soc Sci Med. 2015;131:131-46. doi: 10.1016/j.socscimed.2015.02.025

14. Stahl T, Wismar M, Ollila E, Lahtinen E, Leppo K (Eds.). Health in All Policies: prospects and potentials. Finland: European Observatory on Health Systems and Policy [Internet]. 2006 [cited 2019 Feb 14]. Available at: http://hiaconnect.edu.au/old/files/Health_in_All_Policies.pdf

15. World Health Organization-WHO. World Conference on Social determinants of Health. Closing the gap: policy into practice on social determinants of health. WHO Discussion Paper [Internet]. 2011 [cited 2019 Feb 14];19-21. Available at: http://www.who.int/sdhconference/Discussion-Paper-EN. pdf?ua $=1$

16. Clavier C, Gendron S, Lamontagne L, Potvin L. Understanding similarities in the local implementation of a health environment programme: insights from policy studies. Soc Sci Med. 2012;75:171-8. doi: 10.1016/j.socscimed.2012.02.044

17. Borrell C, Morrison J, Burstrom B, Pons-Vigués M, Hoffmann R, Gandarillas A, et al. Comparison of health policy documents of European cities: are they oriented to reduce inequalities in health? J Public Health Pol. 2013;34:100-20. doi: 10.1057/jphp.2012.57

18. Ottersen OP, Dasgupta J, Blouin C, Buss P, Chongsuvivatwong V, Frenk J, et al. The political origins of health inequity: prospects for change. The Lancet-University of Oslo Commission on Global Governance for Health. Lancet. 2014;383:577-8. doi: 10.1016/S0140-6736(13)62407-1

19. Diba D, d'Oliveira AF. Teatro e comunidade, juventude e apoio social: atores da promoção da saúde. Cien Saude Colet. 2015;20:1353-62. doi: $10.1590 / 1413-81232015205.01542014$

20. Eugenio JL, Mendoza MLM, Figueroa IV, Amezcua JMM. Movilización sociale y determinantes socials de la salud: proceso educativo en comunidad rural de Jalisco, México. Revista de Estudios Sociales [Internet]. 2015 [cited 2019 Feb 16];23:139-61. Available from: http://www. scielo.org.mx/pdf/estsoc/v23n46/v23n46a6.pdf

21. Alia KA, Freedmam DA, Brandt HM, Browne T. Identifying emergent social networks at a Federally Qualified Health Center-Based Farmers' Market. Am J Community Psychol. 2014;53:335-45. doi: 10.1007/s10464-013-9616-0

22. Nascimento PR, Westphal MF, Moreira RS, Baltar VT, Moysés ST, Zioni F, et al. Impact of the Social Agendas - Agenda 21 and Healthy Cities - upon Social Determinants of Health in Brazilian municipalities: measuring the effects of diffuse social policies through the dimensions of the Millennium Development Goals. Rev Bras Epidemiol. 2014;17(Supl-2):1-14. doi: 10.1590/1809-4503201400060001

23. Pons-Vigués M, Diez È, Morrison J, Salas-Nicás S, Hoffmann R, Burstrom B, et al. Social and health policies or interventions to tackle health inequalities in European cities: a scoping review. BMC Public Health. 2014;14:1-12. doi: 10.1186/1471-2458-14-198

24. García-Ramírez JA, Vélez-Álvarez C. América Latina frente a los determinantes sociales de la salud: políticas públicas implementadas. Rev Salud Publica [Internet]. 2013 [cited 2019 Feb 18];15:731-42. Available from: https://pesquisa.bvsalud.org/portal/resource/pt/lil-709099

25. Alvarez CV, Merchan MEP, Potes MDPE. “Determinantes Sociais da Saúde e Trabalho Informal”. Rev Saúde Pública Costa Rica. 2013;2:155-162.

26. Mendel P, Ngo VK, Dixon ERN, Stokdale S, Jones F, Chung B, et al. Partnered evaluation of a community engagement intervention: use of a kickoff conference in a randomized trial for depression care improvement in underserved communities. Ethn Dis [Internet]. 2011 [cited Feb 18]; 21:78-88. Available from: https://pubmed.ncbi.nlm.nih.gov/22352084/

27. O'Brien BC, Harris IB, Beckman TJ, Reed DA, Coo DA. Standards for reporting qualitative research: a synthesis of recommendations. Acad Med. 2014;89(9):1245-51. doi: 10.1097/ACM.0000000000000388

28. The EQUATOR Network: Enhancing the quality and transparency of health research [Internet]. 2019 [cited 2019 Feb 20]. Available at: http:// www.equator-network.org.

29. Instituto Brasileiro de Geografia e Estatística (IBGE): aglomerados subnormais - informações territoriais [Internet]. 2017 [cited 2019 Feb 20 ]. Available from: http://www.ibge.gov.br/home/presidencia/noticias/imprensa/ppts/00000015164811202013480105748802.pdf

30. Habermas J. Teoría de La acción comunicativa. Madrid: Taurus; 1988.

31. Aragão L. Habermas: filosofo e sociólogo do nosso tempo. Tempo Brasileiro; 2002.

32. Campos GWS, Bedrikow R, Santos JÁ, Terra LSV, Fernandes JA, Borges FT. Direito à saúde: o Sistema Único de Saúde (SUS) está em risco? Comun Saúde Educ. 2016;20(56):261-6. doi: 10.1590/1807-57622015.0409

33. Almeida PF, Santos AM. Diálogos em busca de coordenação do cuidado: linha de chegada ou novo itinerário? In: Almeida PF, Santos AM, Souza MKB. Atenção primaria à saúde na coordenação do cuidado em regiões de saúde. EDUFBA. Salvador. 2015; 309.

34. Silveira CB, Jorge MSB, Leitão IMTA. As redes de atenção à saúde e suas interfaces: processos de trabalho, atenção primária à saúde e produção do cuidado integral. In: Bessa MS, Bezerra JIC, Leitão IMTA. Pesquisas em saúde no contexto do cuidado, redes de atenção, fluxos e avaliação: multiplicidade de olhares. Fortaleza: EdUECE, 2017.

35. Fertonani HP, Pires DEP, Biff D, Scherer MDA. Modelo assistencial em saúde: conceitos e desafios à atenção básica brasileira. Ciên Saúde Coletiva. 2015;20(6):1869-78. doi: 10.1590/1413-81232015206.13272014

36. Paim JS. A Reforma sanitária brasileira e o Sistema Único de Saúde: dialogando com hipóteses concorrentes. Physis Rev Saúde Coletiva. 2008;18(4):625-44. doi: 10.1590/S0103-73312008000400003

37. Habermas J. Na esteira da tecnocracia: pequenos escritos políticos XII. São Paulo: Editora UNESP; 2014. 
38. Accorsi A, Scarparo H, Guareschi P. A naturalização da pobreza: reflexões sobre a formação do pensamento social. Psicol Soc. 2012;24(3):53646. doi: 10.1590/S0102-71822012000300007

39. Holston J. Cidadania insurgente: disjunções da democracia e da modernidade no Brasil. São Paulo: Companhia das Letras; 2013.

40. Palácio do Planalto (BR). Decreto no. 9.276 de 2 de fevereiro de 2018. Dispõe sobre a programação orçamentária e financeira, estabelece o cronograma mensal do desembolso do Poder Executivo federal para o exercício de 2018 e dá outras providências [Internet]. 2018 [cited 2019 Mar 04]. Available from: http://www.planalto.gov.br/ccivil_03/_ato2015-2018/2018/decreto/D9276.htm 